\title{
Immunolocalization of Basic Fibroblast Growth Factor and Its Receptor in Adult Goldfish Retina
}

\author{
Pamela A. Raymond, ${ }^{1}$ Linda K. Barthel, and Mary Ellen Rounsifer \\ Department of Anatomy \& Cell Biology, The University of Michigan, Ann Arbor, Michigan 48109-0616
}

\begin{abstract}
The neural retina of teleost fish can regenerate following surgical or neurotoxic lesions. As a first attempt to uncover the factors important for the regenerative response, we used immunocytochemistry to demonstrate the presence of basic fibroblast growth factor (bFGF) and its receptor in the goldfish retina. The bFGF-immunoreactivity was present throughout the retina, but was most intense in photoreceptor cells, especially cones, and Múller glia. Immunoreactivity for the bFGF receptor was strongest in the axon terminals of photoreceptors, both rods and cones. This pattern of immunolocalization is especially interesting since the proliferating cells that are thought to be responsible for generating the neural regenerate are located among the photoreceptor axon terminals. These proliferating cells have been identified as rod precursors because in the intact retina they give rise only to rod photoreceptors. When the neural retina is damaged, however, rod precursors are thought to be the source of proliferating neuroepithelial cells responsible for generating the retinal regenerate. The role played by bFGF in normal neurogenesis, cell differentiation, and/or neuronal regeneration in the fish retina has yet to be determined. 1992 Academic Press, Inc.
\end{abstract}

\section{INTRODUCTION}

The neural retina in juvenile and adult fish can regenerate following surgical or neurotoxic destruction (10, $14,15)$. The neuroepithelial cells that give rise to the retinal regenerate are thought to derive from a population of scattered proliferating cells located in the photoreceptor cell layer of the differentiated retina (15). These proliferating cells have been identified as "rod precursors" because in the intact retina they produce rod photoreceptor cells which are continuously generated and inserted into the growing retina of the adult fish (8). Continued neurogenesis in the adult central nervous system is an unusual event. The cellular environment of the fish retina, unlike most differentiated

\footnotetext{
${ }^{1}$ Pamela A. Raymond has published previonsly as P. R. Johns.
}

neural tissue, must therefore have the constituents necessary to sustain proliferation and differentiation of neurons. Among the components that must be present in the cellular milieu are growth factors $(1,5)$, and we have chosen to direct our attention to the family of fibroblast growth factors (FGFs), which have been shown to stimulate differentiation and maintenance of photoreceptors $(3,7)$ and to enhance neurite outgrowth from cultured retinal ganglion cells (9). Further evidence for the importance of these growth factors in retina is the demonstration that regeneration of embryonic chick retina is dependent on an exogenous supply of bFGF (13). In order to determine whether FGFs might be important for retinal regeneration in fish, we first asked whether they are present in the intact adult retina.

\section{MATERIALS AND METHODS}

Goldfish (Carassius auratus) were purchased from a local pet store and were 4 to $6 \mathrm{~cm}$ body length (eye diameter, 3.0 to $4.0 \mathrm{~mm}$ ). Eyes were cryoprotected, embedded, frozen, and sectioned at $3 \mu \mathrm{m}$ according to our previously published procedure (2). Some tissue was frozen without fixation, the sections were fixed in methanol or acetone at $-20 \mathrm{C}$, air-dried, and used immediately for immunocytochemistry; other eyes were fixed in $4 \%$ paraformaldehyde before freezing. To label dividing cells, 0.5 to $1.0 \mu \mathrm{l}$ of $1 \mathrm{mM}$-5-bromo-2'-deoxyuridine (Sigma) was injected into the eye to achieve an estimated intraocular concentration of $50 \mu \mathrm{M}$.

The general procedures for immunofluorescence were as described previously (2). Polyclonal antibodies against bFGF were obtained from five different sources: R\&D Systems (Minneapolis, MN); Sigma Chemical (St. Louis, MO); Biomedical Technologies (Stoughton, MA); Collaborative Research, (Bedford, MA); and a gift from A. Baird. Rabbit polyclonal antibody against the bFGF receptor was from Upstate Biotechnology (Lake Placid, NY). Preimmune serum for the bFGF receptor antiserum was kindly provided by the manufacturer.

To demonstrate that the antibodies to mammalian FGF recognized the fish FGF homologue, Western blots were prepared of proteins from goldfish brain. To en rich for bFGF, homogenates were extracted with acid 
RAYMOND, BARTHEL, AND ROUNSIFER

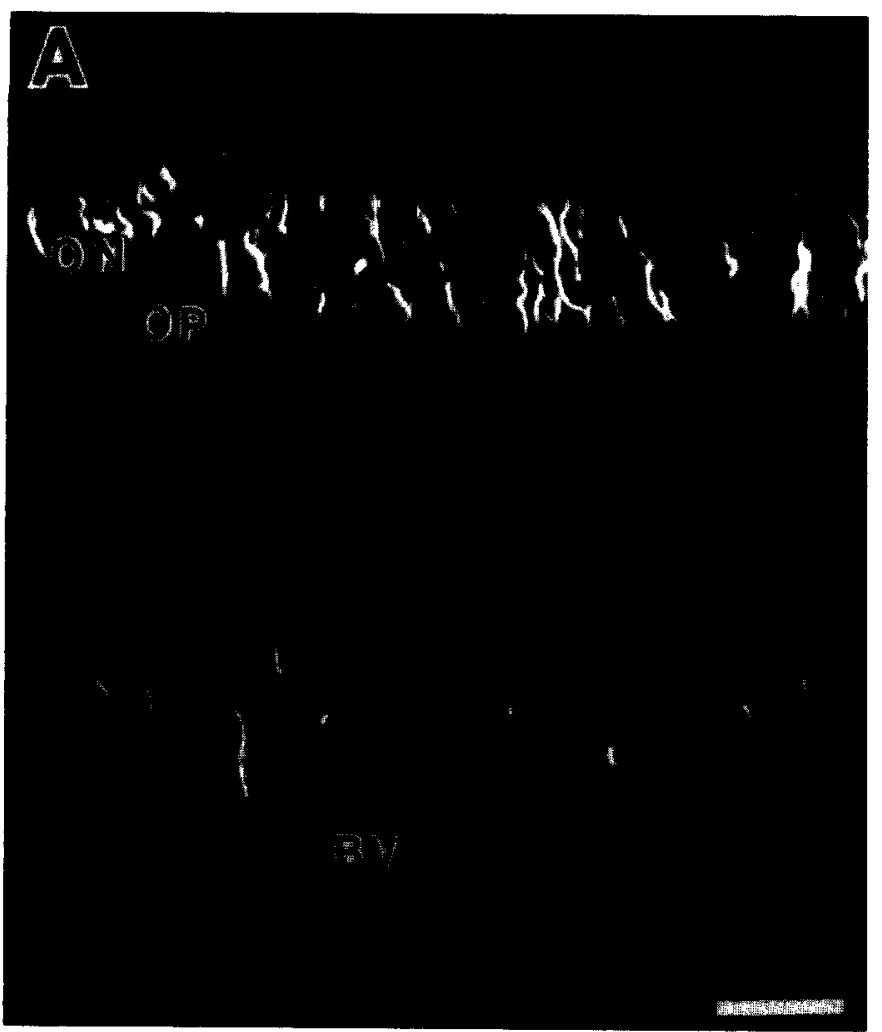

19,

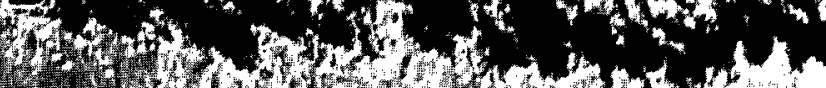
(3)

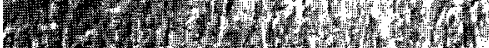

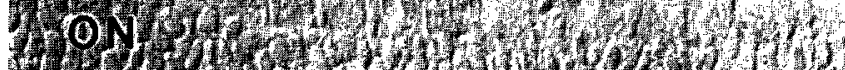

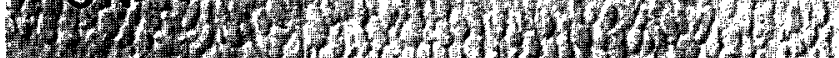

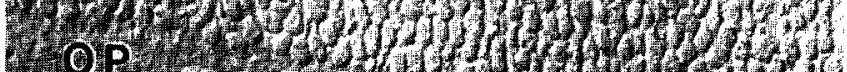

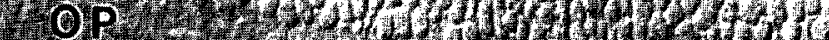

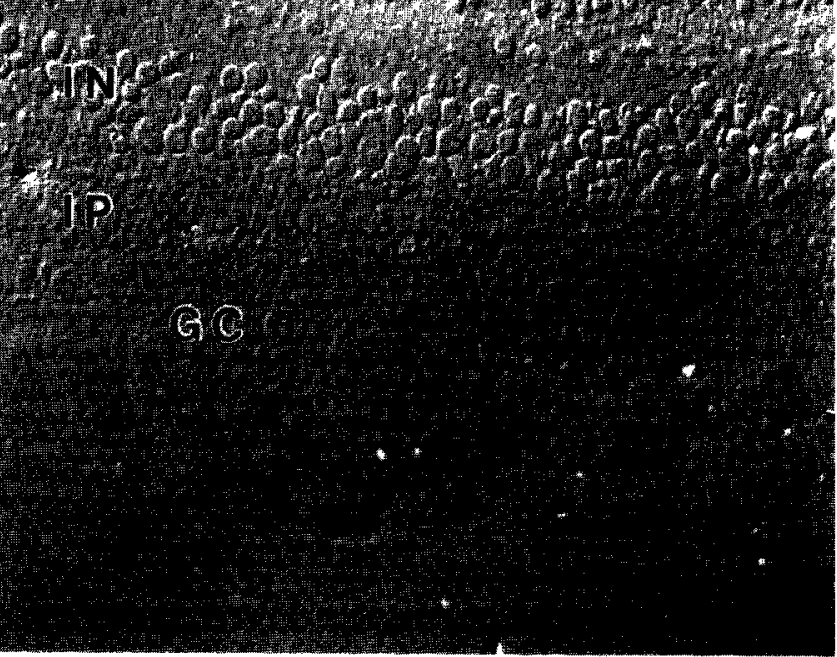

\section{(}

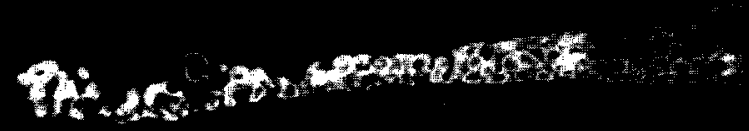

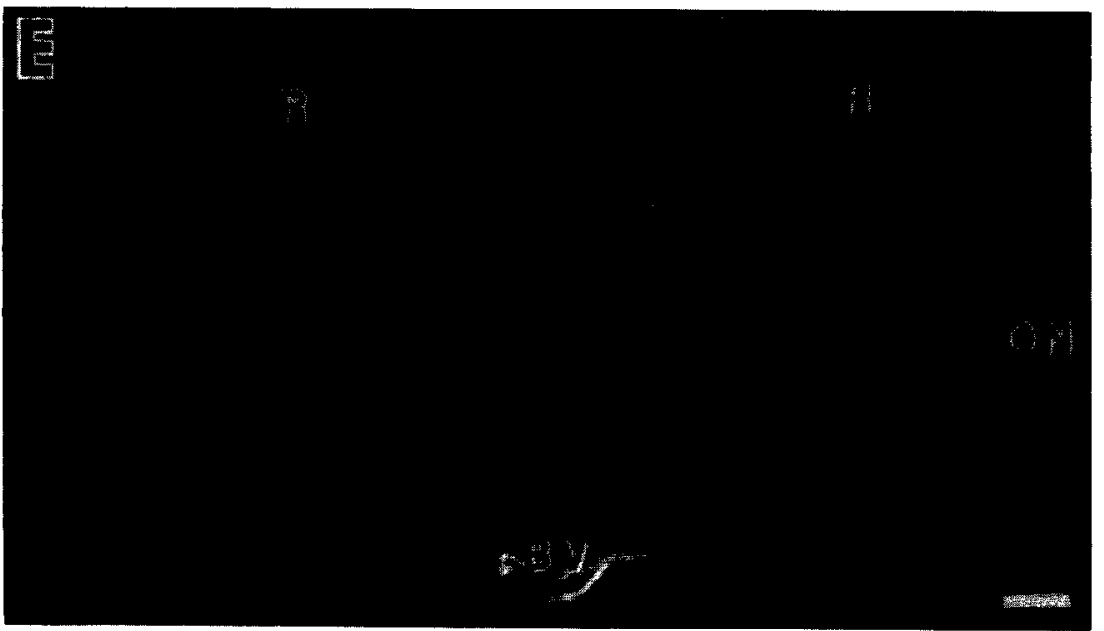




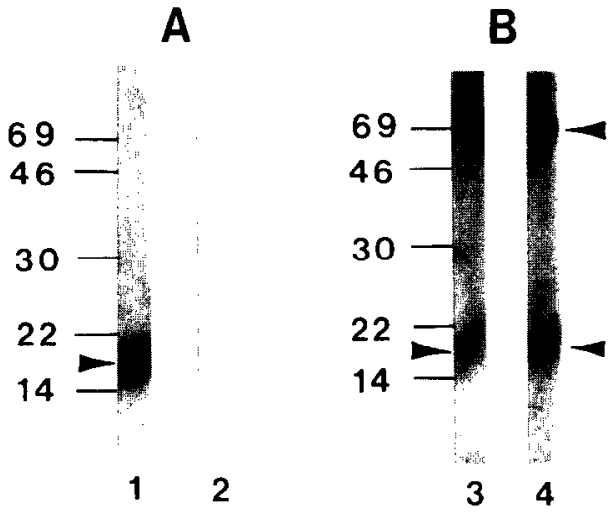

FIG. 2. Western blots of bFGF purified from adult goldfish brain. A, Lanes 1 and 2 were loaded with $10 \mu \mathrm{g}$ of protein from fish brain (purified on a heparin-Sepharose column); lane 1 was incubated in $2 \mu \mathrm{g} / \mu \mathrm{l}$ affinity-purified anti-bovine antibody (R \& D Systems) that had been preabsorbed with bovine serum albumin (BSA); lane 2, primary antibody ommitted. Lane 1 shows a single band at approximately $18 \mathrm{kDa}$. Similar results were obtained with antibodies against human recombinant bFGF from Collaborative Research. B, Lane 3 was loaded with $10 \mu \mathrm{g}$ of heparin-purified fish brain protein and lane 4 with $50 \mathrm{ng}$ commercial bovine bFGF. Both lanes were incubated in affinity-purified anti-bovine bFGF $(13 \mu \mathrm{g} / \mu \mathrm{l})$. Lane 4 shows a band at $18 \mathrm{kDa}$, which corresponds to bovine bFGF; there is a second band at $69 \mathrm{kDa}$, which represents the BSA carrier in the bFGF sample. Lane 3 shows one band at the same relative molecular mass as bovine bFGF.

and passed over a heparin-Sepharose column (4). Proteins were separated by discontinuous SDS-PAGE, transferred to Immobilon-P membranes (Millipore, Bedford, MA), and incubated in bFGF antiserum. Bound antibody was visualized with ${ }^{125}$ I or with avidinbiotin-peroxidase (Vector Laboratories, Burlingame, NJ) conjugated to secondary antibodies. Native bovine FGF (R \& D Systems) was used in Western blots as a control.

\section{RESULTS}

Localization of bFGF in goldfish retina. Staining patterns varied depending on the source of the antibody and the fixation; fresh-frozen tissue gave the most reliable results. Immunoreactivity was distributed throughout the retina (Fig. 1). Prominent staining of radial fibers of Müller glia and the somata and axons of cone photoreceptors was observed with three of the five antibodies (Figs. 1A, 1D, and 1F). Inner segments of rod photoreceptors were immunoreactive with some antibodies (Figs. 1E and $1 \mathrm{~F}$ ). Horizontal cells and the pigmented retinal epithelium were immunoreactive in paraformaldehyde-fixed tissue with two of the antibodies (14). The germinal zone at the retinal margin, the site of active neuroepithelial cell proliferation associated with retinal growth, was negative (Fig. $1 \mathrm{C}$ ). The cornea and iris epithelium (Fig. 1C) and endothelial cells (Figs. 1A, $1 \mathrm{C}, 1 \mathrm{E}$, and $1 \mathrm{~F}$ ) showed strong immunoreactivity with all antibodies tested.

Anti-bovine bFGF antibody recognizes a single band of approximately $18 \mathrm{kDa}$ on Western blots of fish brain proteins. Anti-bovine bFGF antibodies recognized a single band of relative molecular mass 18,000 on Western blots of proteins from goldfish brain purified with a heparin-sepharose column and separated by gel electrophoresis (Fig. 2A). This putative goldfish bFGF had the same molecular mass as bovine bFGF (Fig. 2B).

Immunoreactivity to $b F G F$ receptor is found predominately in axon terminals of photoreceptors. Antibody against the bFGF receptor showed intense immunostaining at the base of the outer nuclear layer in the region of specialized axon terminals of photoreceptors (Fig. 3A). Sections incubated with preimmune serum showed no staining in this region (Fig. 3B). With avidin-biotin-immunoperoxidase, immunoreactivity was localized to the club-shaped axon terminals of photoreceptors (Fig. 3C). Rod precursors are located in approximately the same substratum as the photoreceptor terminals, but in order to identify rod precursors on cyrosections it is necessary to first label them with a mitotic marker such as bromodeoxyuridine (Fig. 3D). Double label studies with antibodies against bromodeoxyuridine and the bFGF receptor demonstrate that rod precursors do not show immunoreactivity for bFGF receptors (not illustrated).

FIG. 1. Immunolocalization of bFGF in goldfish retina. A, Antibody from Sigma (1:100 dilution) shows diffuse immunoreactivity in the outer nuclear (ON) and outer plexiform layers (OP), but the strongest staining is in radial fibers identified as cone photoreceptor axons in the $\mathrm{ON}$ and radial processes in the inner retina identified as Müller glia (also see D). Blood vessels (BV) on the vitreal surface are also labeled. B, The same field as in A shown with Nomarski interference contrast optics. Inner nuclear layer, IN; inner plexiform layer, IP; ganglion cell layer, GC. C, The corneal epithelium (C), annular ligament in the iris angle (A), iris epithelium (I), and blood vessels are immunoreactive with all bFGF antibodies; this example is from Biomedical Technologies Inc. (BTI, diluted 1:50). The germinal zone (GZ) at the retinal margin is not labeled. D, The antibody from Collaborative Research (1:50) showed especially prominent labeling of radial Müller fibers (arrowheads); note the prominent end feet at the vitreal surface and the cell bodies in the inner nuclear layer. Cell bodies of cone photoreceptors and their axons (arrows) are also labeled. E, With antibodies from BTI (1:50) and, F, Collaborative Research (1:100) inner segments of rod photoreceptors (R) are immunoreactive and appear as scattered dots in the subretinal space. Müller fibers are not recognized by the BTI antibody. All tissue shown here was fresh frozen and fixed in $70 \%$ methanol. Calibration bars are $25 \mu \mathrm{m}$; the one in $\mathrm{A}$ applies also to $\mathrm{B}$ and $\mathrm{D}$, and the one in $\mathrm{E}$ also to $\mathrm{F}$. 


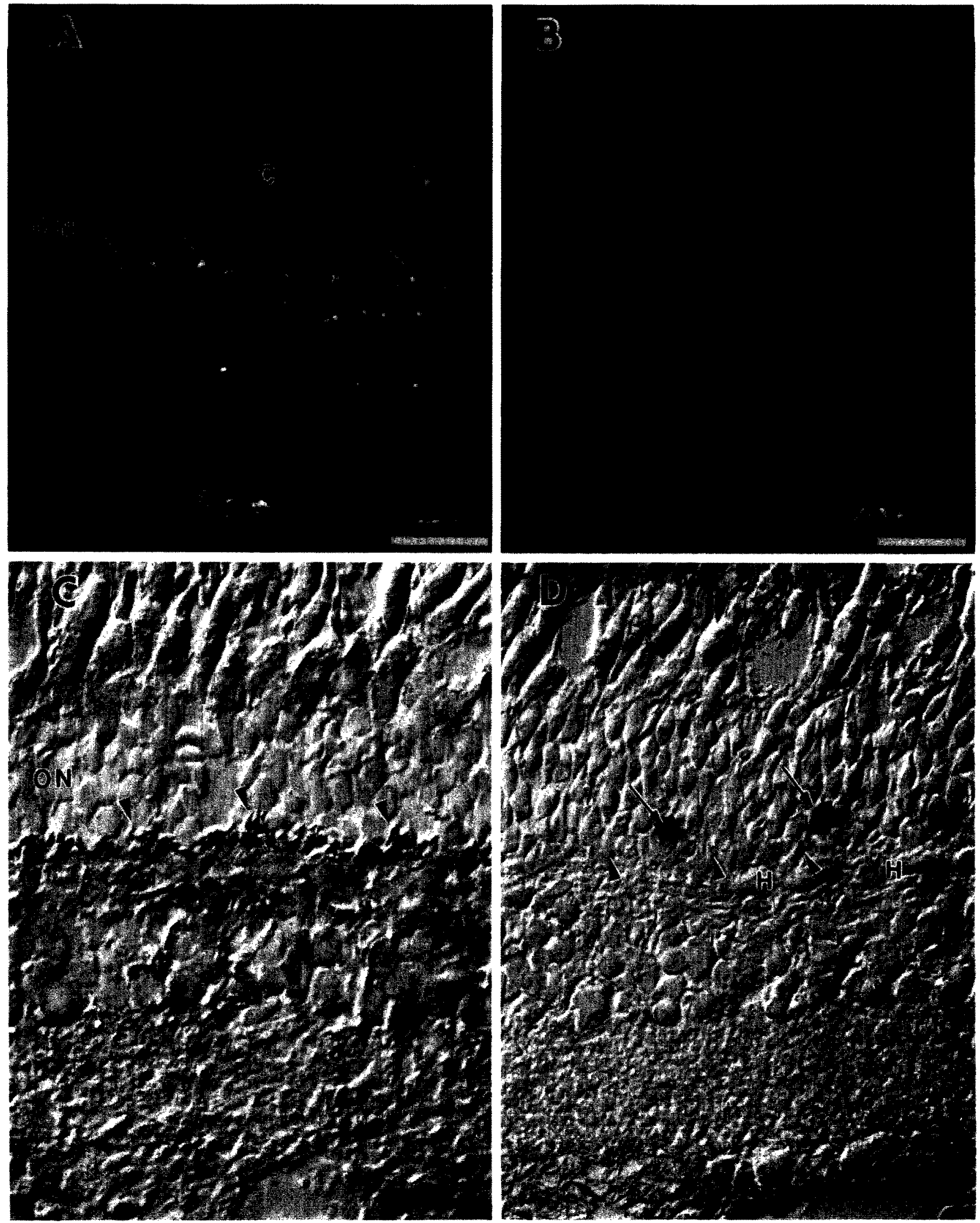




\section{DISCUSSION}

These studies have demonstrated that differentiated neurons and glial cells in the goldfish retina are immunoreactive for bFGF and its receptor. Immunoreactivity for bFGF is seen predominately in photoreceptors, especially cones, and Müller glia, whereas the axon terminals of both cones and rods are intensely immunoreactive for the bFGF receptor. Endothelial cells, cornea, iris, and the retinal pigmented epithelium are also immunoreactive for bFGF.

The presence of both basic and acidic FGF in neural retina has been established biochemically: for example, aFGF and bFGF have been isolated and purified from bovine rod outer segments (12) and from the avascular chick embryo retina (11). Cultured bovine RPE cells (18) and human retinoblastoma cells (17) express the gene for bFGF and have been shown to synthesize bFGF in vitro. There are only a few immunocytochemical studies of the distribution of FGF in retina, however. In bovine retina, immunoreactivity for bFGF is confined to developing capillary endothelial cells (6), but in lamprey, as in goldfish, bFGF immunoreactivity is distributed widely throughout the retina (16). The functional role of FGFs in the development, differentiation, and maintenance of retinal neurons, especially photoreceptors, is not yet understood. The diverse biological activities of these growth factors and the enormous variety of cell types that respond to them guarantee that the answer will not be simple. In the goldfish retina, the distribution of bFGF and its receptor suggest that it might be important for differentiated functions in photoreceptors. Furthermore, since bFGF has been implicated in retinal regeneration in chick embryos (13), it may also play a supportive role in the regeneration of neural retina in fish, which depends on mitotic activation of rod precursors (15).

\section{ACKNOWLEDGMENTS}

Gifts of antisera from R\&D Systems, Upstate Biotechnology, and Dr. Andrew Baird are gratefully acknowledged. George R. Wilmot provided valuable technical assistance with the Western blotting. Supported by NIH EY04318 to P.A.R.

\section{REFERENCES}

1. BaIRD, A., AND P. BoHLEN. 1990. Fibroblast growth factors. In Peptide Growth Factors and Their Receptors I. Handbook of Experimental Pharmacology (M. B. Sporn and A. B. Roberts, Eds.), Vol. 95/I, pp. 369-418. Springer-Verlag, New York.

2. BARThel, L. K., AND P. A. RAymond. 1990. Improved method for obtaining $3-\mu \mathrm{m}$ cyrosections for immunocytochemistry. $J$. Histochem. Cytochem. 9: 1383-1388.

3. Faktorovich, E. G., R. H. Steinberg, D. Yasumura, M. T. MATTHES, AND M. M. LAVAIL. 1990. Photoreceptor degeneration in inherited retinal dystrophy delayed by basic fibroblast growth factor. Nature 347: 83-86.

4. Gospodarowicz, D., J. Cheng, G.-M. Lui, A. Baird, and P. BOHLEN. 1984. Isolation of brain fibroblast growth factor by heparin-Sepharose affinity chromatography: Identity with pituitary fibroblast growth factor. Proc. Natl. Acad. Sci. USA 81: 6963 6967.

5. Gospodarowicz, D., AND G. NeUfELd. 1987. Fibroblast growth factor: Molecular and biological properties. In MesenchymalEpithelial Interactions in Neural Development. (J. R. Wolff, J. Sievers, and M. Berry, Eds.), Vol. 5, pp. 191-221. NA'TO-ASI Series H. Springer-Verlag, New York.

6. Hanneken, A., G. A. LutTty, D. S. McLeod, F. Robey, A. K. HARVEY, AND L. M. HJELMELAND. 1989. Localization of basic fibroblast growth factor to the developing capillaries of the bovine retina. J. Cell. Physiol. 138: 115-120.

7. Hicks, D., AND Y. CouRToIs. 1988. Acidic fibroblast growth factor stimulates opsin levels in retinal photoreceptors in vitro FEBS Lett. 234: 475-479.

8. JoHNS, P. R. 1982. Formation of photoreceptors in larval and adult goldfish. J. Neurosci. 2: 178-198.

9. Lipton, S. A., J. A. Wagner, R. D. Madison, And P. A. D'Amoke. 1988. Acidic fibroblast growth factor enhances regeneration of processes by postnatal mammalian retinal ganglion cells in culture. Proc. Natl. Acad. Sci. USA 85: 2388-2392.

10. MAIER, W., AND H. WolbURG. 1979. Regeneration of the goldfish retina after exposure to different doses of ouabain. Cell Tissue Res. 202: 99-118.

11. Mascarelli, F. Raulais, D. Counis, M. F., and Courtois, Y. 1987. Characterization of acidic and basic fibroblast growth factors in brain, retina and vitreous in chick embryo. Biochem. Biophys. Res. Commun. 31: 478-486.

12. Mascarelli, F., Raulais, D., and Courtois, Y. 1987. Fibro-

FIG. 3. A, Immunofluorescent staining of a $3-\mu \mathrm{m}$ cryosection of paraformaldehyde-fixed goldfish retina with antiserum to the bFGF receptor, diluted 1:1000. Note the intense staining (arrowheads) at the base of the outer nuclear layer (ON), in the region of the synaptic terminals of photoreceptor cells. There is scattered punctate staining in the inner layers of retina including endothelial cells (E) at the vitreal surface. The inner segments of cones (C) show some endogenous fluorescence. B, Control (preimmune antiserum), diluted 1:1500. Note nonspecific staining of erythrocytes at the bottom of the panel (arrowhead). Calibration bars are $25 \mu \mathrm{m}$. C, Immunoperoxidase staining of goldfish retina with antiserum to bFGF receptor, diluted 1:2000. Nomarski interference contrast optics. The stained profiles (arrowheads) at the base of the $\mathrm{ON}$ are photoreceptor axon terminals. D, Immunoperoxidase staining of goldfish retina following injection of bromodeoxyuridine to label dividing rod precursors. The two labeled rod precursor nuclei (arrows) are located immediately contiguous to the photoreceptor axon terminals (arrowheads) that are immunoreactive for bFGF receptor (panel $\mathrm{C}$ ). $\mathrm{H}$, horizontal cell bodies. Calibration bars for $\mathrm{C}$ and $\mathrm{D}$ are $10 \mu \mathrm{m}$. 
blast growth factor phosphorylation and receptors in rod outer segments. EMBO J. 8: 2265-2273.

13. Park, C. M., and M. J. Hollengerg. 1989. Basic fibroblast growth factor induces retinal regeneration in vivo. Dev. Biol. 134: 201-205.

14. RaYmond, P. A. 1991. Cell determination and positional cues in the teleost retina: Development of photoreceptors and horizontal cells. In Development of the Visual System (D. M. K. Lam and C. Shatz, Eds.), Vol. 3, pp. 59-78. Retina Res. Found. Symp., MIT Press, Cambridge, MA.

15. Raymond, P. A., M. J. ReIFler, AND P. K. Rrvlin. 1988. Regen- eration of goldfish retina: Rod precursors are a likely source of regenerated cells. J. Neurobiol. 19: $431-463$.

16. RuBINSON, K. 1991. Distribution of basic fibroblast growth factor in developing lamprey retina. Invest. Ophthal. Vis. Sci. Suppl. 32: 1299.

17. SCHWEigerer, L., G. NeUfeld, AND D. Gospodarowicz. 1987. Basic fibroblast growth factor is present in cultured human retinoblastoma cells. Invest. Ophthal. Vis. Sci. 28: 1838-1843.

18. Schweigerer, L., B. Malerstein, G. Neufeld, AND D. GospoDARowicz. 1987. Basic fibroblast growth factor is synthesized in cultured pigment epithelial cells. Biochem. Biophys. Res. Commun. 143: 934-940. 